\title{
Channels Ran Through It- The Lawrence Formation at Lone Star Lake, Douglas County, Kansas
}

\author{
Paul Enos, Robert D. Jefferson, ${ }^{1}$ and Staci L. Goetz ${ }^{2}$ \\ University of Kansas \\ Lawrence, KS 66045
}

${ }^{1}$ Present address: GX Technology Corporation, 225 E 16th Ave, Suite 1200, Denver, CO 80203

${ }^{2}$ Present address: Earth Tech, Inc., 4135 Technology Parkway, Sheboygan, WI 54301

\begin{abstract}
The upper part of the Ireland Sandstone Member of the Lawrence Formation exposed in the spillway of Lone Star Lake, southwest of Lawrence, Kansas, consists of abundant pinstripe-bedded shales and siltstones; thin, lenticular sandstone and siltstone beds; and meter-scale, channel-form sandstone and mudstone lenses. Soft-sediment-deformation structures, including load casts, ball-and-pillow, and pseudonodules are abundant. The lenticular and pinstripe bedding with bipolar paleocurrents suggests tide-influenced deposition. The crosscutting, channel-form deposits are interpreted as tidal channels in an environment with low energy but rapid sedimentation. The depositional environment was a tide-dominated, muddy upper estuary cut by tidal channels. Gravitational instabilities resulting from rapid deposition of sand over saturated mud produced inverse-density gradients that resulted in soft-sediment deformation.
\end{abstract}

\section{Introduction}

The upper part of the Ireland Sandstone Member of the Lawrence Formation exposed in the spillway of Lone Star Lake, $9 \mathrm{mi}(14.5 \mathrm{~km})$ southwest of Lawrence, Douglas County, Kansas (fig. 1), is a sequence of shale, siltstone, and sandstone with many deformed intervals. Primary sedimentary structures and deformational structures provide clues as to depositional environment and processes. Measurement and correlation of the structures at the Lone Star spillway were undertaken to improve understanding of these processes and environments. The resulting interpretations support, and to some extent modify, existing theories on the depositional history of the upper part of the Ireland Sandstone Member.

The Lawrence Formation of the Douglas Group (Upper Pennsylvanian, Stephanian) forms the base of the Virgilian Series as it is now interpreted (figs. 2 and 3). The Lawrence Formation consists chiefly of gray claystone, mudstone, siltstone, and sandstone, which weather yellowish gray, and small intervals of red claystone, coal, gray limestone, and conglomerate (Ball, 1964; Zeller, 1968; Rutan, 1980). The formation extends from the base of the Haskell Limestone Member to the base of the Toronto Limestone Member of the Oread Formation (fig. 2). The study interval, beneath the lower Williamsburg coal, technically belongs to the Ireland Sandstone Member (fig. 2), but it has little in common with the namesake channel-form sandstone, lithologically and perhaps genetically. The sandstone channel is $100 \mathrm{ft}(30 \mathrm{~m})$ thick in southern Douglas County where it cuts deep into the Weston Shale Member (O’Connor, 1960) and 160 $\mathrm{ft}(50 \mathrm{~m})$ thick in adjacent Franklin County (Sanders, 1959), but becomes thinner and more shaly in central and northern Douglas County until it "cannot be differentiated" (O'Connor, 1960, p. 36).

The Lone Star spillway, "The Grand Canyon of Douglas County" (nom. nov.), exposed approximately $27 \mathrm{~m}$ of the uppermost Lawrence Formation following severe erosion during a flash flood of 30 June 1988, when up to 12.2 inches of rain fell in the area (Lawrence Journal-World, 30 June 1988). The lower $10.5 \mathrm{~m}$ of the section, the focus of this study, underlies a coal bed that Bowsher and Jewett (1943, p. 52) and Lanier (1993, p. 4-8) correlated with the lower Williamsburg coal (fig. 3). This entire interval was covered by a thick layer of concrete when the spillway was rebuilt in 1997.

\section{Prior Work}

Stanton Ball (1964) provided by far the most detailed study of the Douglas Group in Kansas, before there was adequate exposure at Lone Star Lake. Sanders (1959) and O'Connor (1960) provided important stratigraphic details for northeastern Kansas and Douglas County, respectively. Studies by Rutan (1980), Archer (1991, 1993), Archer and West (1991), Lanier (1993), Archer et al. (1994), Joeckel (1994, 1995), and Archer and Feldman (1995) dealt with the sedimentology at or near the Lone Star site. Lanier (1993, p. 4-6) described the section below the lower Williamsburg coal as a coarsening-upwards succession of pinstripe- and lenticular-bedded mudstones; flaser-bedded, fine-grained, micaceous sheet sandstones; and channels with accretionary fillings marked by inclined, heterolithic bedding and convoluted bedding. Lanier interpreted the section as a shoalingupwards, prograding, muddy tidal-flat sequence with a repetitive depositional style characterized by a continuum of punctuated (waning-energy) sedimentation events (1993, p. 4-9).

Lanier (1993) observed that channel-form sandstones below the lower Williamsburg coal exhibit climbing-ripple drift lamination in a finer-grained facies that consists of lenticular- and 


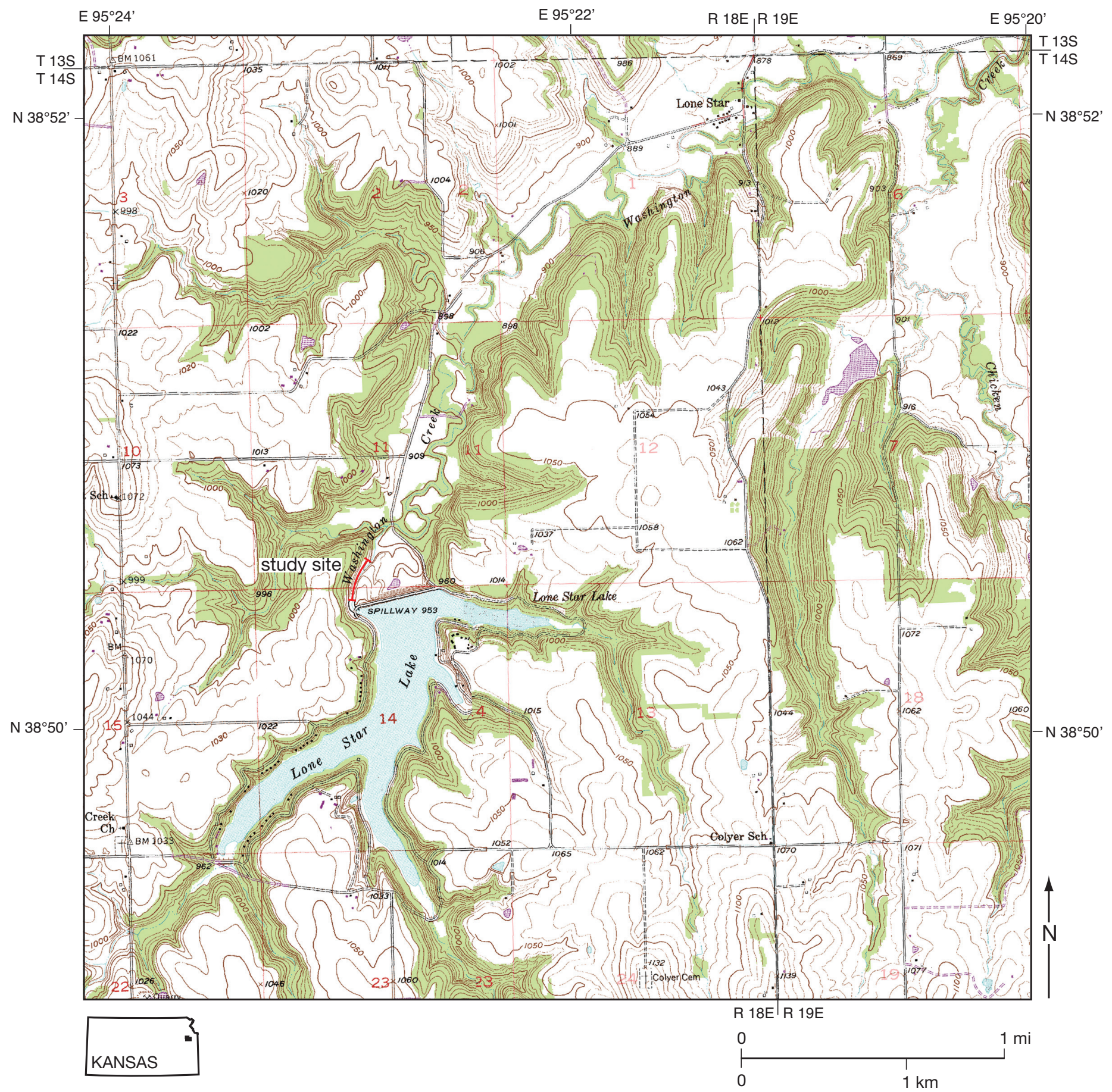

FIGURE 1-Location of the study area in the spillway of Lone Star Lake. Spillway connects to Washington Creek below the dam. Base maps are from the Lone Star and Globe sheets, U.S. Geological Survey 7.5-min topographic quadrangles.

flaser-bedded, heterolithic sandstones and shales. This part of the section is interpreted as a tidal deposit (Archer and West, 1991, p. 89; Archer et al., 1993; see also Lanier and Tessier, 1998). The Lawrence Formation immediately above the lower Williamsburg coal consists of rhythmic silt and shale laminae with systematic thickness variations interpreted as neap-spring tidal cycles (Archer, 1991, 1993, p. 2-21-2-23).

West and Maples (1993, p. 7-6) summarized the paleoecology of the Douglas Group and "suggest that the Douglas Group represents a range of environments from nearshore marine to freshwater and terrestrial...." Trace fossils are locally numerous in the Lawrence Formation (Hakes, 1972, 1976; Robb, 1991;
Garbish et al., 1991; Lanier, 1993). In the bathymetric trace-fossil classification developed by Seilacher (1967), the trace fossils of the Lawrence Formation appear to fit best in the Scoyenia facies (Hakes, 1972, p. 32). Scoyenia facies indicates low-energy, restricted, nearshore deposits that may be lagoonal or possibly brackish (Hakes, 1972, p. 33). Scott Hageman (in Robb, 1991, p. 49-52) described a variety of plant fossils, some with attached spirorbid worm tubes, from the carbonaceous shale that forms the upper part of the Williamsburg coal. He concluded, "The spirorbids and plant debris were probably in a shallow, freshwater or slightly brackish environment because the spirorbids attach to the leaves and the leaves grew in that type of environment." 


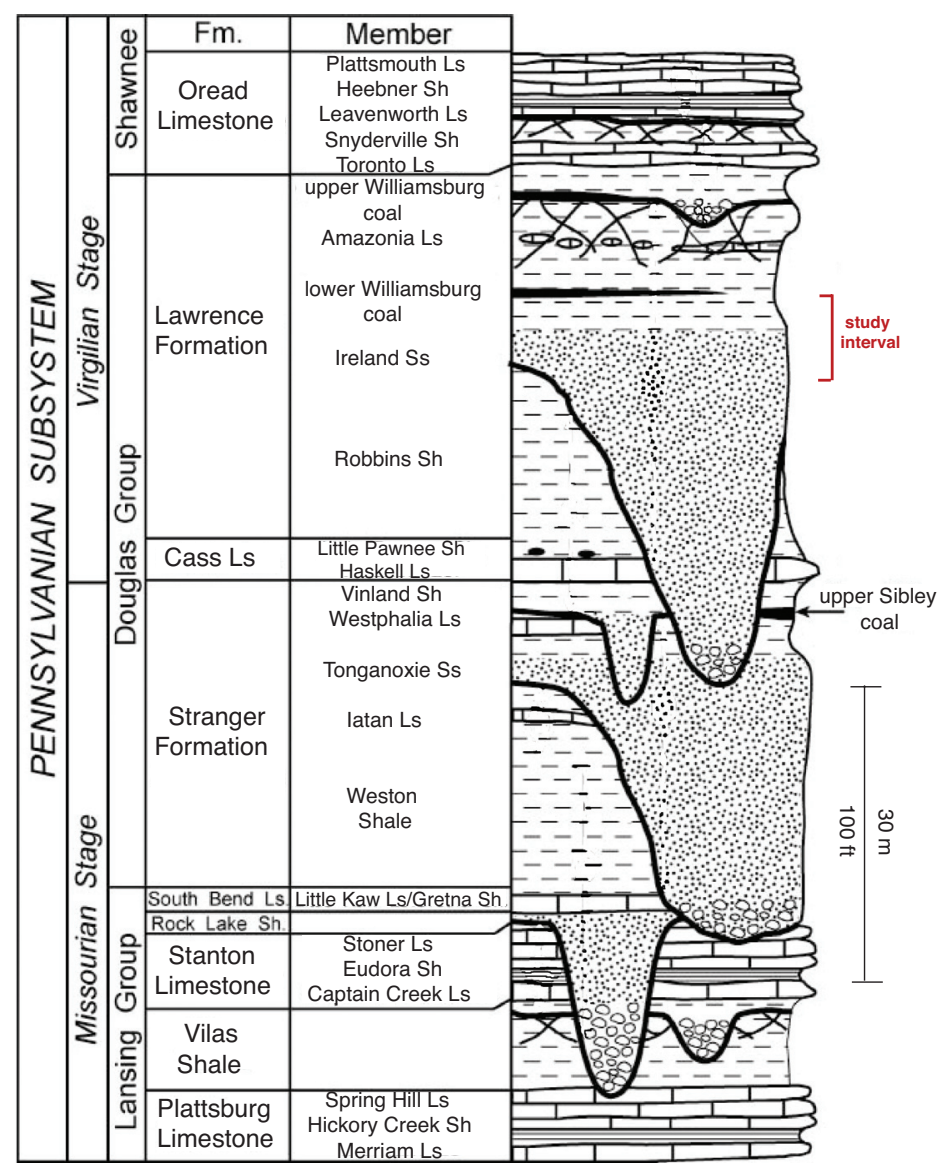

FIGURE 2-Stratigraphic nomenclature of the Douglas Group and adjacent units (modified from Feldman et al., 2005, and Archer and Feldman, 1995; after Zeller, 1968). The study interval is in the upper part of the Ireland Sandstone Member of the Lawrence Formation and extends through the lower Williamsburg coal. The study site lies north of the main channel incision of the Ireland, exposed in southern Douglas and northern Franklin counties. The Ireland Sandstone Member extends to the base of the Amazonia Limestone Member and thus includes the lower Williamsburg coal (Ball, 1964, p. 142). The Amazonia Limestone Member and an overlying thin coal, presumably the upper Williamsburg coal (fig. 3 ), are still exposed at the site, whereas the study interval has been entirely covered by a concrete apron.

\section{Methods}

This project is based on closely spaced sections (fig. 4) measured in the spillway of Lone Star Lake (fig. 5). The outcrop is nearly separated into two intervals. Sections 1 through 7 at the north part of the spillway comprise the lower interval. The upper interval consists of sections 9 through 15 from the south. The upper interval is well exposed only on the left bank, that is, the west side of the spillway. The lower Williamsburg coal was a natural datum for correlation of the upper interval.
A closely spaced sandstone couplet was a useful datum for the lower interval. It extends from section 1 into sections 9 and 10 to provide a tie with the upper interval (figs. 5 and 6). Key beds in the more intricate upper interval were initially traced in the field and eventually on overlapping panoramic photographs (fig. 7).

The sections were measured in detail in 1992 and with considerable overlap in 1994, as part of sedimentology class projects at the University of Kansas. A selection of these sections serves as the input data for this report. Scale of the original sections is $1 \mathrm{inch}=25 \mathrm{~cm}$, or approximately 1:10. Lithology, bedding thickness, and character were recorded graphically (fig. 5). Symbols denote primary sedimentary structures, deformational structures, and particles, including the rare fossils. Rock name, grain size, and any additional comments were noted. Each section was checked and edited in the field by the instructor (Enos). The sections were redrafted for fig. 5 to incorporate field edits, to include observations from both operators in the duplicated sections, and to provide uniform representation.

\section{Results}

The lower Williamsburg coal consists of up to $8 \mathrm{~cm}$ of bituminous coal overlain by up to $30 \mathrm{~cm}$ of carbonaceous shale with abundant plant fossils (fig. 5; Bowsher and Jewett, 1943, p. 52). A striking feature of the unit was several vertical shafts of carbonized wood a meter or more high that represent lycopod trunks buried in growth position (Lanier, 1993, p. 4-8; Archer et al., 1993, p. 1-20-1-22; Archer et al.,1994; apparently destroyed by would-be collectors ca. 1993). Abundant fragmented plant fossils in the carbonaceous shale include Cordaites, Neuropteris, Pecopteris, Calamites, Asterophyllites, Annularia, Sphenophyllum, and Lepidophylloides leaves and Lepidodendron bark (Scott Hageman, in Robb, 1991, p. 50). Spirorbis, a coiled polycheate worm, is attached to leaves of the first three genera. The bivalves Myalina and Aviculopecten are reported from the shale (Robb, 1991, p. 8; Lanier, 1993, p. 4-8); we did not observe these, although myalinids are abundant in the overlying Amazonia Limestone Member (fig. 2). Siderite concretions within the shale have yielded, in addition to well-preserved plant fossils, horseshoe crabs, cockroaches, shrimp, and arachnids (Archer et al., 1993, p. 1-20).

That part of the Lawrence Formation exposed below the lower Williamsburg coal consists of mudstone, "pin-stripe" shales, siltstones, and sandstones and lenticular sandstones. "Pin stripe" as used by Lanier (1993; after Klein, 1977) is taken to mean intimate, repetitive interlamination of millimeter-scale siltstone or fine sandstone within shale or mudstone. ${ }^{1}$ Pinstripe lamination is prevalent throughout; lenticular and wavy bedding are common; flaser bedding is confined to a few sandstone-rich units in the upper interval (figs. 7-9).

Immediately below the coal is 20 to $60 \mathrm{~cm}$ of light-gray (5Y5/1), clay-rich, blocky mudstone with poorly developed

'Pinstripe lamination was introduced by Folk (1973, p. 717; "pin-stripe beds" in McBride and Folk, 1979, p. 863) for "remarkable laminae resembling parallel white pencil lines" on chert of the Caballos Novaculite of west Texas. Klein (1977, figs. 42, 43) applied the term to mm-scale sand layers within muddy deposits of modern tidal flats. Kvale and Archer (1990, p. 566) specified that the sandstone layers be discontinuous and equated "pinstripe lamination" with "lenticular bedding" of Reineck and Wunderlich (1968). However, Archer (1993, p. 2-8; Archer and Feldman, 1995 , p. 130) later appended "pinstripe bedding" to the familiar diagram of Reineck and Wunderlich (1968) to denote somewhat more continuous and planar beds than their "lenticular" bedding. That figure is reproduced here as fig. 10, with the altered spelling (no hyphen). 


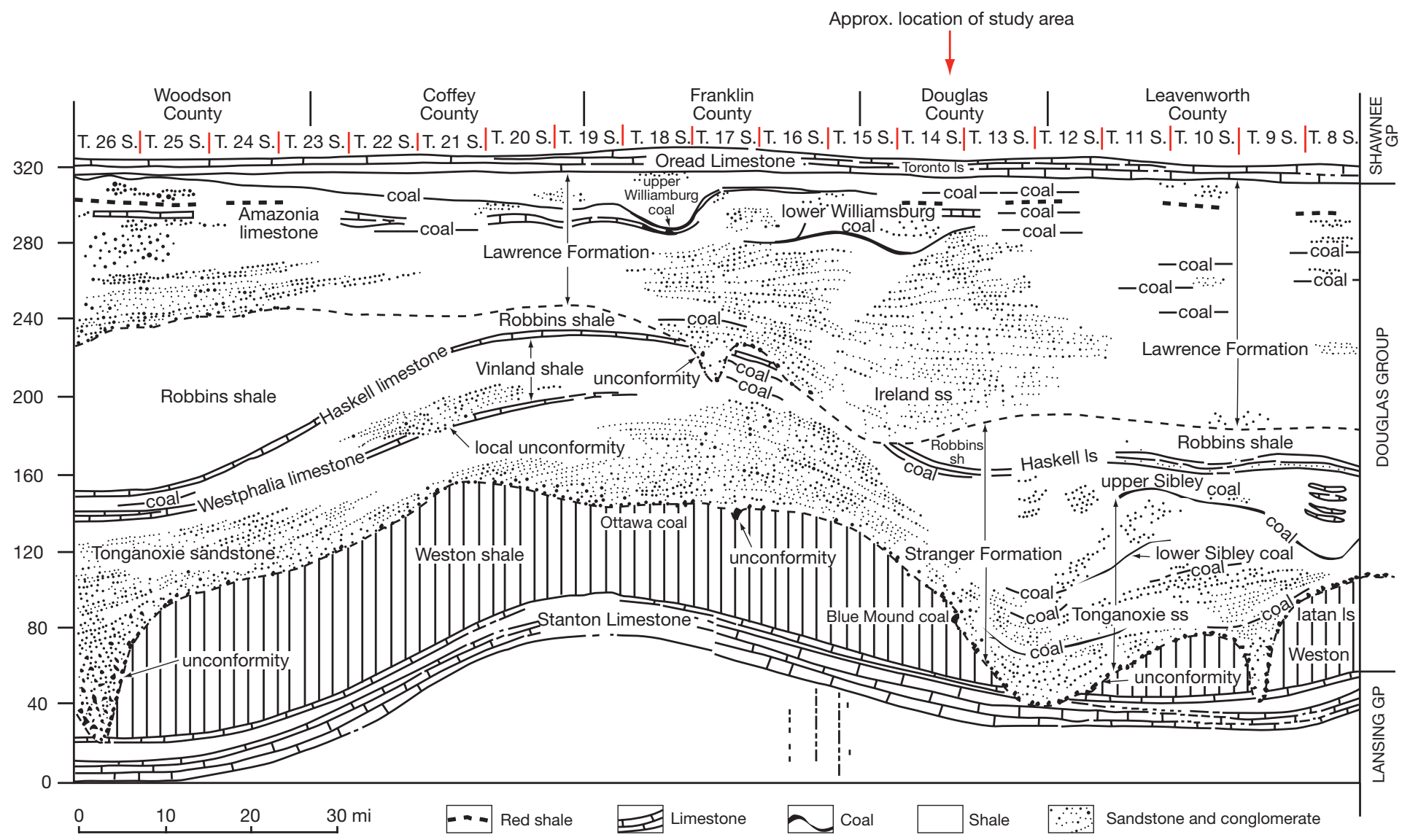

FIGURE 3-Stratigraphic cross section of the Douglas Group in northeastern Kansas (from Moore, 1949; after Bowsher and Jewett, 1943). The Robbins Shale and Haskell Limestone Members are included in the Stranger Formation, rather than in the Lawrence Formation (Zeller, 1968) or the Cass Limestone (fig. 2; Feldman et al., 2005).

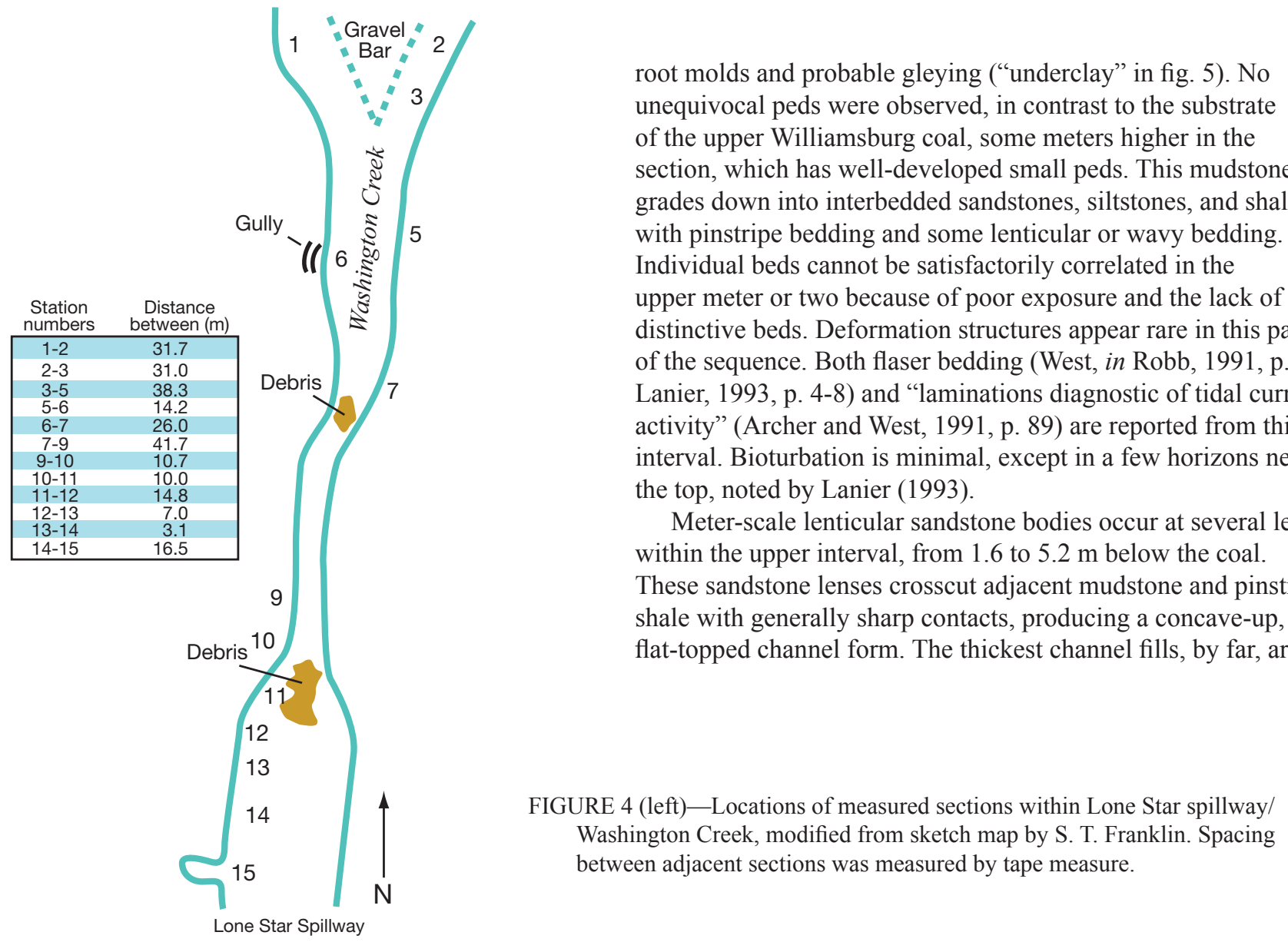


Figure 5 is an over-size figure. Please see enosfigs5and7.pdf to see fig. 5. 


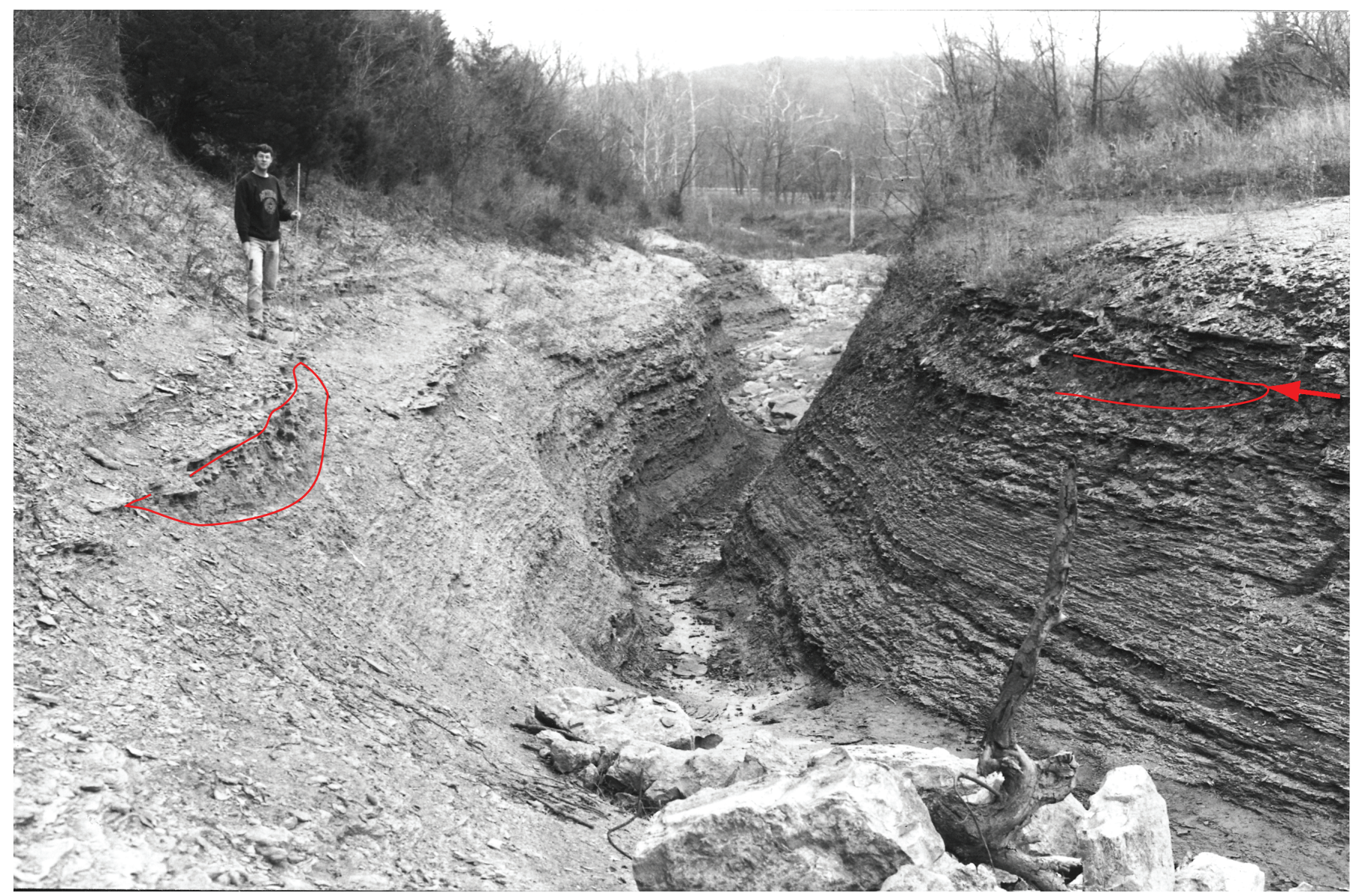

FIGURE 6-View of lower part of spillway at Lone Star Lake, the "Grand Canyon of Douglas County." Exposures are mainly of the lower interval. The scale (S. T. Franklin; $193 \mathrm{~cm}$ ) is standing above a channel-form lens of shale and deformed sandstone within the upper interval (sec. 11, fig. $5 ; 32-41 \mathrm{~m}$ in fig. 7). The channel form on the right bank (arrow) is probably the same lens, suggesting an approximate ENE elongation of the channel form. This orientation is not inconsistent with the NNE-SSW paleocurrent directions measured by Lanier (1993, see fig. 11). However, this trend and a measured trend of $120^{\circ}$ (ESE/WNW) in the channel at 8-16 m contradict Lanier's observation that the "Overall trend of the channel complex appears to be north-south" (Lanier, 1993, p. 4-8). The apparent difference in elevation of the two channel exposures is an artifact of the camera angle. Lateral continuity is good in the underlying beds on both sides of the exposure.

$1.4 \mathrm{~m}$ (fig. 7, 3-9 m and 8-16 m, fig. 8). ${ }^{2}$ Most are filled with sandstone with inclined bedding or ripple-cross lamination and internal truncations (fig. 7, 8-16 m). All the sandstone is very fine grained, but thinner bedding and predominance of siltstone toward the tops of channel forms defines finingupward sequences. Filling of the channel forms was generally asymmetric with gently inclined beds (fig. 8). Opposing current directions were measured from adjacent ripple cross-laminated beds (fig. 9) within the channel-form sandstone at 8-16 m (figs. 7, 8). Additional paleocurrent directions were recorded on measured sections 15, 14, 13, and 9. Lanier (1993, p. 4-7) presented a rose diagram of 50 paleocurrent measurements from throughout the Lawrence Formation at Lone Star spillway. Most of the measurements are apparently from our study interval below the lower Williamsburg coal (Lanier, 1993, p. 4-6 to 4-8), where inclined bedding is prevalent and exposure is much more extensive. The paleocurrents are strongly bimodal, with modes directed N and SSW (fig. 11).
Several channel forms are filled almost entirely with mudstone (e.g. fig. 5, sections 9, 10, and 15; fig. 7, 3-9 m and $33-41 \mathrm{~m}$ ). Any sandstone and siltstone within these channels is confined to ball-and-pillow lenses, presumably the remnants of thin sand or silt layers. Identifying mud-filled channels within the predominate mudstone presents challenges, but truncation, particularly of coarser lithologies, is evident at the margins.

Each channel form is at a unique stratigraphic level. Channel margins overlap or truncate one another in some cases, but none is of exactly the same age as is demonstrated by tracing the thin capping sandstone or siltstone beds from one channel to another. Channel forms are so lenticular, occur in such abundance, and are so lacking of unique features that it is hazardous to attempt to correlate them without continuous exposures, even across the few tens of meters separating the opposite sides of the spillway. Two channel forms were tentatively correlated from the west wall to the east to provide an indication of their trends. The most prominent channel form, near the southern end of the

${ }^{2}$ The very muddy fill of the 3-9-m channel (fig. 7) may have undergone considerable compaction. The slight upward bulge of the overlying beds (fig. 7) indicates less compaction than that in the enclosing heterolithic facies, however. Adjacent sand-filled channels (e.g. fig. 7, 8-16 m) commonly show a sag in overlying beds, suggesting incomplete fill. 
Figure 7 is an over-size figure. Please see enosfigs5and7.pdf to see fig. 7. 


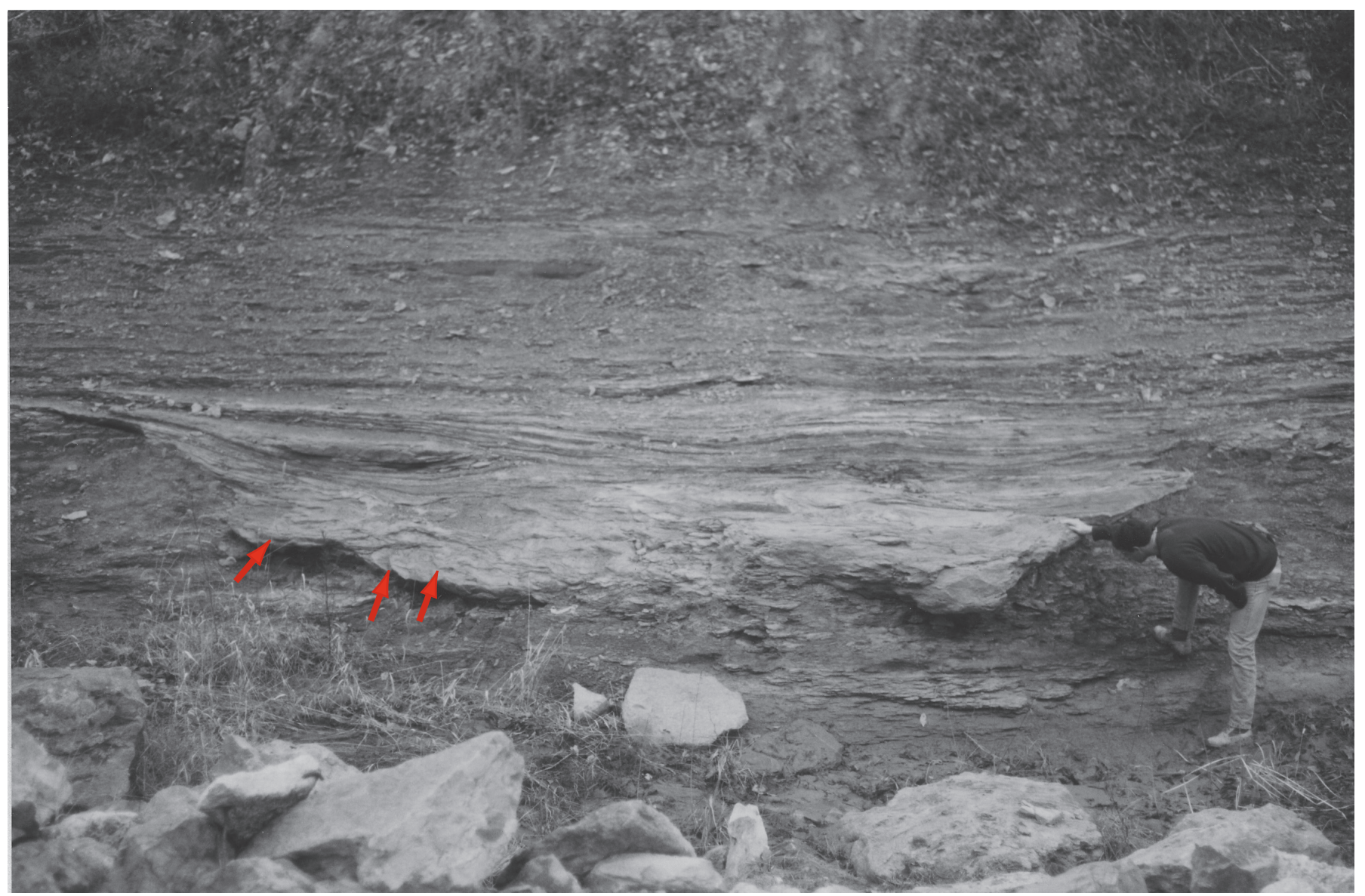

FIGURE 8- Largest of channel forms within the upper interval of the Lawrence Formation (8-16 m, fig. 7). Thin sandstone beds filling the channel form generally dip gently to the right (north). Intense deformation, mainly ball-and-pillow structures, is visible on both sides of the channel and beneath it. Load casts are present within the lower part of the channel form, especially toward the left margin (arrows).

studied exposure (fig. 7, 8-16 m; fig. 8), is elongated in an ESE/ WNW direction $\left(120^{\circ}\right)$. The channel form at $32-41 \mathrm{~m}$ (fig. 7) is elongated approximately ENE/WSW (fig. 6).

Sediments were extensively deformed at the margins of many channel-form sandstones (figs. 5, 7, 8). Deformation structures associated with channel forms are mostly ball-and-pillow structures or pseudonodules, some up to decimeter scale. These are in contrast to the small load casts scattered throughout the thinner-bedded portions of the outcrop. Convolute lamination is common, generally associated with load casts or pseudondules.

Pinstripe and lenticular bedding are prevalent in the lower interval of study (fig. 5) where channel-form sandstones are absent. Lateral continuity of thin beds is striking, notably the datum couplet, which can be traced throughout the exposure for $195 \mathrm{~m}$ (fig. 5, sections 1-10). Bioturbation is minimal. Deformation structures are widely and patchily distributed, but a cluster of load casts and pseudonodules just below the lower datum couplet can be traced through sections 1 to 10 (fig. 5). Most structures are small load casts. A recumbent penecontemporaneous fold with limbs tens of centimeters long extends from section 1 to 3 (fig. 5). Clay diapirs disrupt siltstone beds in sections 3 and 7 (fig. 5).

\section{Interpretations}

The dramatic preservation of the carbonized tree trunks within the lower Williamsburg coal at the top of the study interval attests to the rapidity of sediment deposition (Gradzinski and Dokter, 1995) in this unit, buried by tidal rhythmites (Archer, 1993, p. 2-21; Lanier, 1993, p. 4-8). The upper parts of the preserved trunks, more than a meter high, extend well into the pinstripe rhythmites. The thin coal, sandwiched between apparent tidal deposits (see below) and replete with brackish to marine biota (Spirorbis, Myalina, and Aviculopecten) in the upper part, apparently formed in a paralic swamp. Nodules within the upper shaly part of the coal contain an eclectic assemblage of plants and terrestrial and brackish-water arthropods (Archer et al., 1993, p. 1-20), demonstrating a considerable contribution from the lowrelief hinterland.

The light-gray clayey mudstone with probable root molds subjacent to the lower Williamsburg coal is interpreted as underclay, representing the leached soil on which a coal-forming swamp developed.

Pinstripe, lenticular, wavy, and flaser bedding of shale, siltstone, and sandstone (fig. 10) that dominate within the studied interval of the Lawrence Formation can form in various depositional settings. However, in combination and abundance, they are very suggestive of tidal processes (Reineck and 


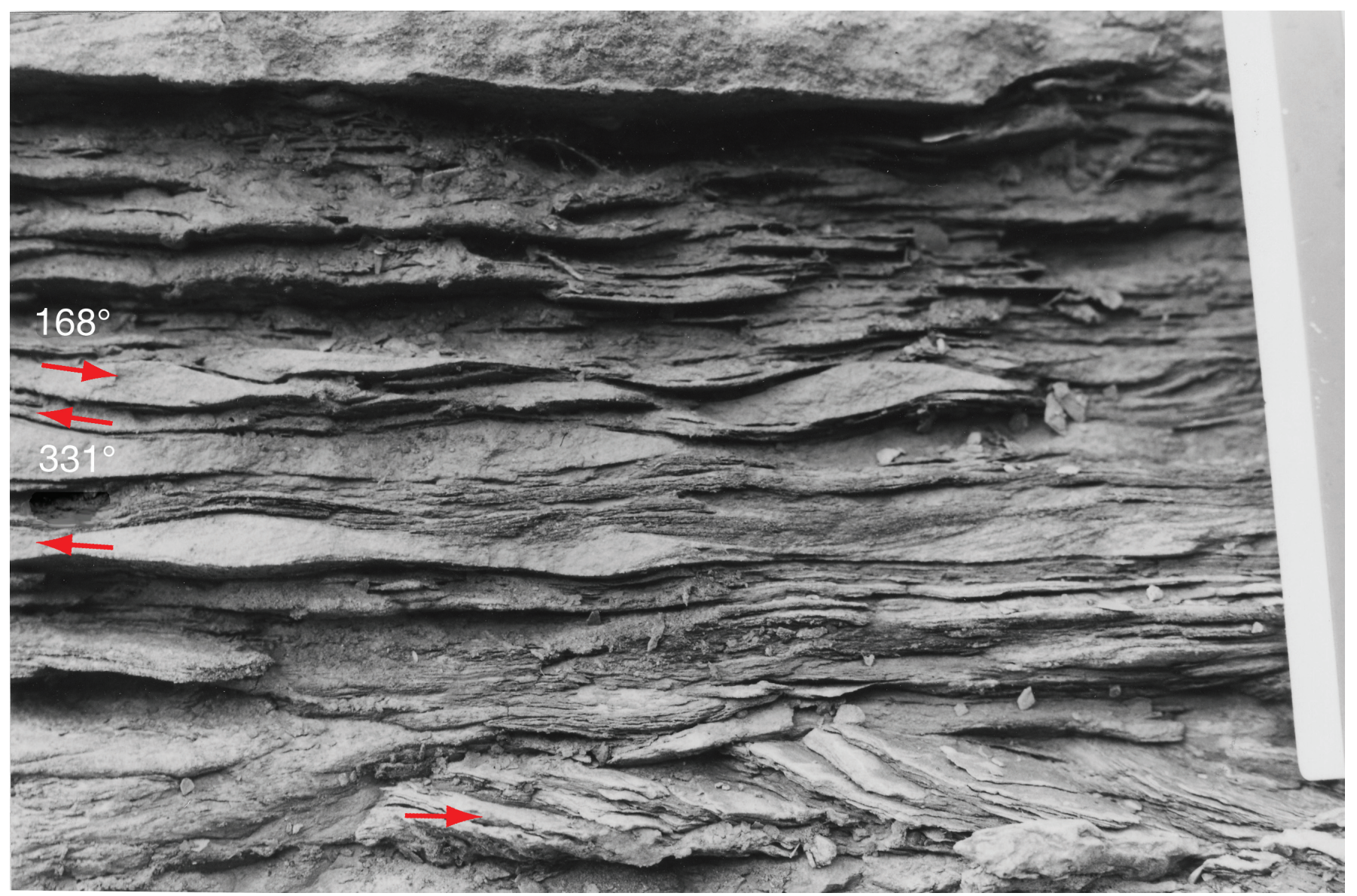

FIGURE 9-Ripple-drift cross lamination in flaser-bedded sandstone and siltstone at the south (left) margin of the channel form in fig. 8 (9 m, fig.

7). Medium-scale inclined bedding, deeper within channel, dips toward the right (north) at the bottom of the photo. Arrows show approximate paleocurrent directions from ripple lamination; numbers record measured paleocurrent directions. Bimodality is prominent (see fig. 11). Scale (right) is $15 \mathrm{~cm}$ long.

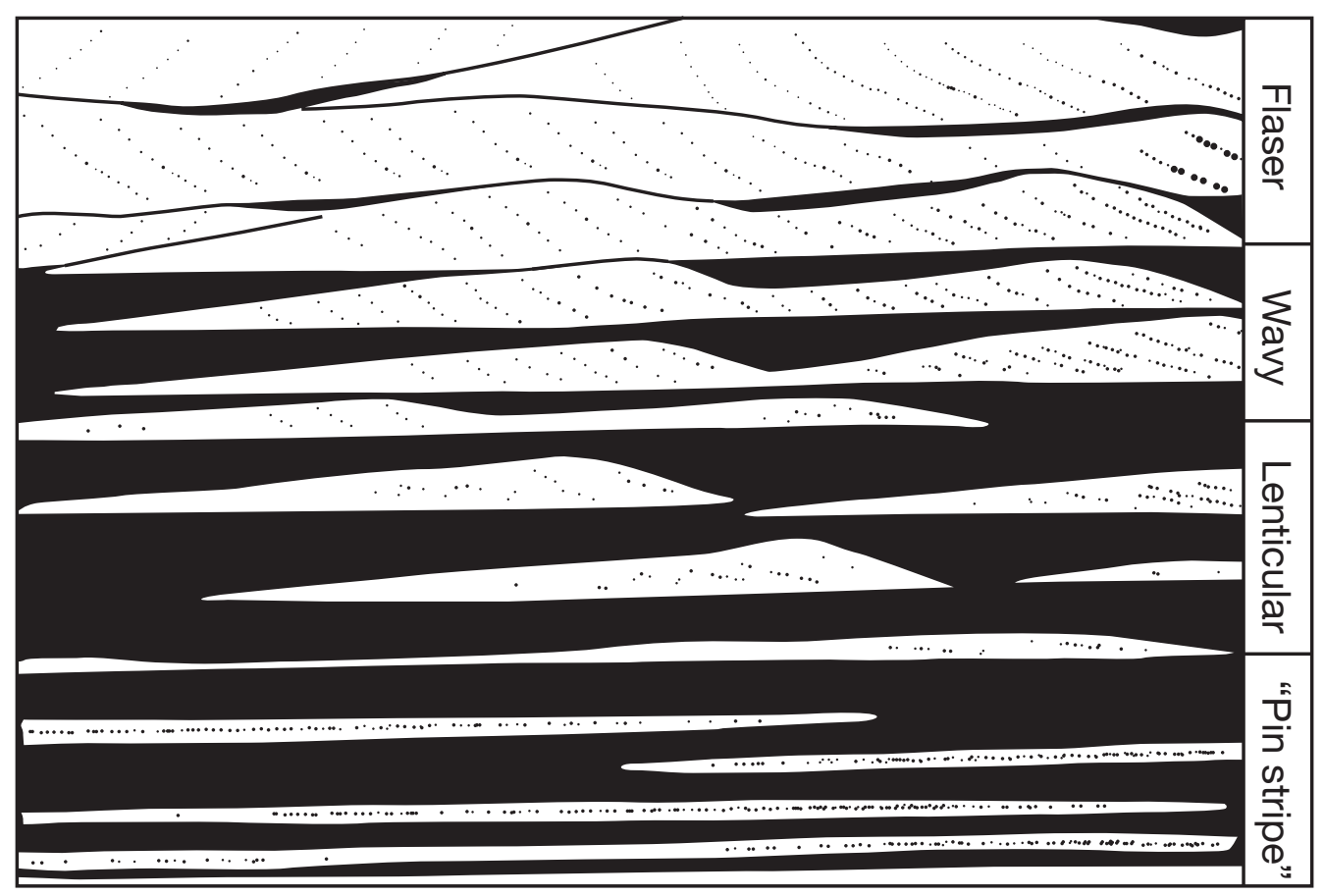

FIGURE 10-Relationships of flaser, lenticular, wavy, and "pin stripe" bedding. These types of bedding, sometimes referred to as "tidal bedding" (Wunderlich, 1970; Reineck and Singh, 1975, p. 108), are characteristic of, but not restricted to, tidal environments where sedimentation alternates between bed load and suspension load (from Archer and Feldman, 1995, p. 130; modified after Reineck and Wunderlich, 1968). 
Wunderlich, 1968; Reineck, and Singh, 1975, p. 108; Archer, 1993, p. 2-8). More definitive evidence of tidal influence comes from analysis of thickness variations in siltstone-mudstone couplets in vertical sequence from the interval immediately overlying the lower Williamsburg coal. The variations show a wave-form repetition of thickening and thinning with a maximum wave length of 14 depositional events, interpreted as representing a lunar hemicycle of diurnal tides with thicker spring-tide and thinner neap-tide deposits (Archer, 1991, 1998). Fluctuations in current strength, in which traction transport in current ripples alternates with suspension sedimentation, results in lenticular, wavy, or flaser bedding (Reineck and Wunderlich, 1968). Lanier (1993, p. 4-9) observed cycles of bedding from pinstripe to lenticular to pinstripe in the Lawrence Formation at the Lone Star spillway, indicating longer-term, repetitive alternation of energy conditions. These he interpreted as neap-spring-neap sequences (Lanier, 1993, p. 4-9). The predominance of pinstripe bedding and the scarcity of flaser bedding presumably result from the predominance of mud over sand and silt, indicating relatively low tidal velocities or disproportionate rates of supply.

Larger, meter-scale sandstone lenses are prominent in the upper sequence (figs. 5, 7, 8). The lenses are interpreted as true channels, rather than slump scars or slide deposits. No slump folding, listric faults, incipient slides, tensional structures, debris beds, or other features indicative of slumps or slides are exposed within the upper sequence. In fact, none has been reported from anywhere within the Lawrence Formation, with the possible exception of the recumbent fold in the lower sequence, discussed below. Extensive deformation within and adjacent to the channels is confined to vertical gravitational deformation resulting from differential loading. Truncation surfaces within the channels are interpreted as internal reactivation surfaces, possibly on a scale of spring-neap cycles, but more likely from channel migration or from superposition of ebb- and flood-dominant channel bars. Detailed correlations based on tracing beds in outcrop indicate that each lens is a discrete channel intersected by the exposure, not segments of meandering channels that weave in and out of the plane of exposure, because each lens occurs at a unique stratigraphic level. The minimal lateral extent of the channels indicates a lack of lateral migration, typical of channels in the middle or upper tidal flats (cf. Weimer et al., 1982). The shallow depth of the channels, judged from thickness of fill, also suggests a position high on the tidal flats, or a microtidal regime (less than 2 -m range). Allowing for compaction or incompleteness of fill (see footnote 2) could push the range to mesotidal. Allen Archer (1993, p. 2-28) has argued that low tidal ranges result in low sedimentation rates and, consequently, greater bioturbation. He concludes that "nonbiturbated heterolithic rhythmites [like those at Lone Star], based upon modern analogs, appear to require at least mesotidal conditions."

Bipolar reversing paleocurrent directions (fig. 9) measured within a channel are consistent with the bimodal, bipolar current directions, diagnostic of tidal currents, measured throughout the sequence by Lanier (1993; fig. 11).

The asymmetrical filling of channels (fig. 8; fig. 7, 3-9 m, 8-16 m, 17-21 m [lower of superposed channels], 34-38 m [lower], 48-57 m, 49-51 m? [ higher]) may be indicative of tidal channels rather than subaerial or subaqueous channels, following McKee (1957) and Reineck and Singh (1975, p. 63). Asymmetrical channel filling (fig. 12) is interpreted as a

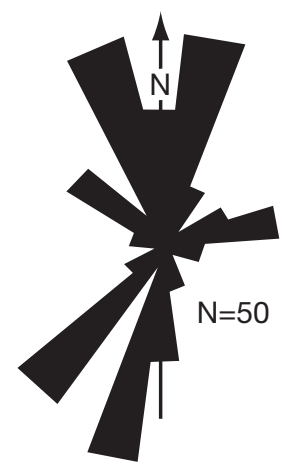

FIGURE 11-Paleocurrent directions from the upper Lawrence Formation at Lone Star Lake spillway, showing strong bimodality (from Lanier, 1993).

product of currents that flow diagonally through the channel, as is commonly observed where intertidal flats are under water, and water flow is controlled to a greater extent by differences in water levels than by surface morphology (Reineck and Singh, 1975, p. $63)$.

The deformational structures in both the upper and lower intervals appear to have resulted from penecontemporaneous softsediment deformation. The structures observed include load casts, pseudonodules, ball-and-pillows, and a recumbent fold (fig. 5). Deformation is confined to a single sandstone-shale couplet, as in load casts, or to a few adjacent couplets in the case of ball-andpillow structures and pseudonodules (definitions of Owen, 1987, 2003a, b). The overlying sand layers are flat and undeformed, even over the most intensely deformed intervals (figs. 7 and 8). Thus deformation occurred near the surface and was essentially completed before deposition of the next layer, perhaps as soon as the next diurnal or lunar tidal cycle.

These structures typically result from gravitational instability due to a reverse density gradient (Owen, 1987, p. 19; Allen, 2003). In the Lawrence Formation, thin sand or silt layers were deposited rapidly, probably within a single tidal cycle, by ripple migration over water-saturated mud. The sand would have an initial porosity of about $40 \%$; water-saturated mud porosities are typically $70 \%$ to $80 \%$ (Beard and Weyl, 1973; Enos and Sawatsky, 1981), so the bulk density of mud would be much lower (cf. Pettijohn et al., 1987, p. 113). Cohesiveness of the mud prevents the sand from settling as single grains. Sand and silt layers settle and disintegrate into blebs wrapped in mud that is concomitantly displaced upward. Judging from the scale and internal lamination, many of the blebs nucleate around individual ripples. This indicates that the slight loading differential introduced by the thickness differences between ripple crests and troughs was sufficient to cause deformation. The muds were indeed weak, but cohesive.

The soft-sediment deformation in the upper interval of the sequence occurs primarily around and within the channels. This again suggests that the weight of the sands deposited onto the muddy layers and the resulting inverse density gradient triggered the deformation. Undercutting at channel margins may have contributed, but no coherent slump or tensional structures were observed. The gravity mechanism drives the deformation concurrent with deposition or, at latest, prior to consolidation (Pettijohn et al., 1987, p. 113). Load deformation is particularly striking in many of the mud-filled channels (fig. 7, 3-9 m and 
33-41 m). The initial configuration of the fill was apparently mud interlayered with sand and silt, but load deformation has reduced the sand and silt beds to pseudonodules and ball-and-pillow structures.

The origin of a recumbent fold, extending between sections 1 and 3 near the base of the sequence (fig. 5) is more enigmatic. The consistently south-verging axes of this fold and smaller synsedimentary folds (fig. 5, section 1 ) are testimony of some slope. Such structures can result from creep or slumping on very low slopes. Repeated cyclic loading of the sediment by tidal flooding might induce incipient liquefaction in sand layers or loss of thixotropy ${ }^{3}$ in the mud, thereby reducing the slope necessary for lateral motion. Slopes, even low slopes, are not prominent features of most tidal flats. Slopes of very different scales can be generated by bank erosion along tidal creeks (Reineck and Singh, 1975, p. 90), through depositional relief on sand waves (Dalrymple et al., 1990) or tidal bars (Reineck and Singh, 1975, p. 80), or by draping over preexisting topography. No channel forms are exposed in the lower sequence where the recumbent folds occur. Depositional relief on low-amplitude bar forms is a possibility in the estuarine setting proposed for this part of the Lawrence Formation by Archer and Feldman (1995), but the lateral persistence of very fine bedding within the lower interval at Lone Star spillway argues against depositional relief within the dimensions of the outcrop. Three incised valleys have been identified within the Douglas Group in northeast Kansas below the level exposed at Lone Star spillway (fig. 2; Ireland and Tonganoxie Sandstone Members, Archer et al., 1994, and a smaller, unnamed one within the Vinland Shale Member, Feldman et al., 2005). Drape over the Tonganoxie Sandstone Member paleovalley had probably been compensated by the time of deposition of the very thin and persistent Haskell Limestone Member (Ball, 1985; fig. 3; the apparent relief is determined by the datum chosen and extreme vertical exaggeration). The Ireland Sandstone Member channel (fig. 2) is stratigraphically and geographically closely subjacent to the interval studied, although the Lone Star locality may lie "in the non-valley-part of the depositional system." (Archer et al., 1993, p. 1-8). Compactional topography with very gentle relief nevertheless seems a possibility. The regional lateral discontinuity of units in the upper Lawrence Formation (fig. 3) could in part reflect such relief.

The sedimentary structures and bedding features observed indicate deposition dominated by tidal processes. A plausible interpretation of the depositional environment is a tide-influenced estuarine environment, as proposed by Archer and West (1991), Archer (1993), Lanier (1993), and Archer and Feldman (1995). The high mud content of the section suggests the relative placement of the sequence in the estuary. Different sections of an estuary system produce different lithofacies distribution. In a modern example of the Gironde Estuary of France (fig. 13; Allen, 1991, Archer, 1993; Archer and Feldman, 1995), the upper estuary ("central estuary" in the widely cited terminology of Dalrymple et al., 1992) is the muddiest portion; shale or mudstone would be the dominant resultant rock. In contrast, the riverine estuary and lower estuary (fig. 13; inner and outer estuary, resp., of Dalrymple et al., 1992) are sandier; sandstone with muddy interbeds would be the expected dominant lithology.

\section{A}

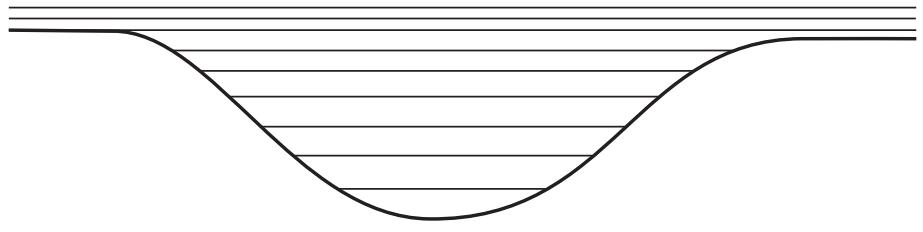

$\mathrm{B}$

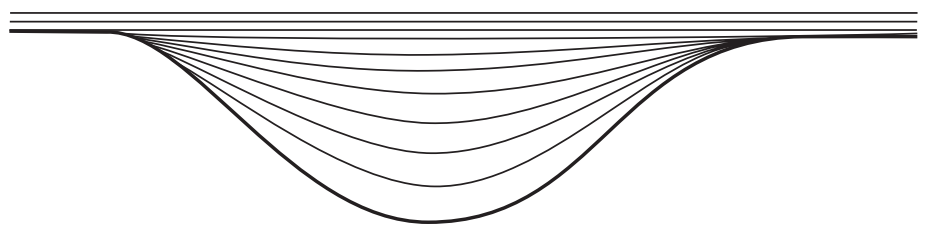

$\mathrm{C}$

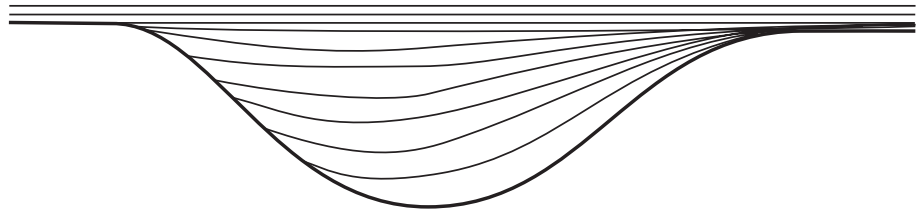

FIGURE 12-Three patterns of channel fill: A) horizontal layers, common in subaerial channels; B) layers conforming approximately to the channel shape, common in subaqueous channels; C) asymmetric fill by inclined layers, common in tidal regimes (from Reineck and Singh, 1975, p. 63; based on McKee, 1957).

Relatively rapid and continuous deposition is indicated by the small amount of burrowing throughout the sequence, the preservation of tree trunks above the coal, and the abundant softsediment deformation. This suggests an abundant sediment flux during the deposition of the sequence, despite the inferred low energy. Several processes can augment the sediment flux in a low-energy setting. Deposition in the turbidity maximum, formed where suspended sediment is trapped at the upstream limit of the saltwater wedge is one such process (Allen, 1991). The limit of the saltwater wedge is controlled primarily by the river discharge, so it can migrate considerably within an estuary. The central estuary is the realm of convergence of marine processes (tides and waves) and river currents (Dalrymple et al., 1992, p. 1,131$)$ with portions of their respective sediment loads. This convergence coupled with low energy sets the stage for rapid deposition. An obvious condition for rapid sedimentation of mud is a large suspended-to-bed-load ratio in the fluvial system at the head of the estuary. Such ratios are favored by humid climates with deep chemical weathering and by rivers that are deep relative to their width. Feldman et al. (2005) presented evidence that the Ireland Sandstone Member valley fill was deposited in a relatively wet seasonal climate, whereas the upper part of the Lawrence Formation was deposited during the transition to drier seasonal climates in the Oread Limestone. The lower Williamsburg coal and the subjacent gray, gleyed paleosol indicate that depostion of the underlying sequence at Lone Star spillway was still under relatively humid conditions.

Tidal rhythmites are reported immediately above the lower Williamsburg coal (Archer, 1993, p. 2-21-2-23) and implied from the interval below the coal (Archer and West, 1991), but no quantitative measures were provided that could be used to

${ }^{3}$ Thixotropy is "the property of certain colloidal substances. . . to weaken or change from a gel to a sol when shaken but to increase in strength upon standing" (Neuendorf et al., 2005, p. 669). 


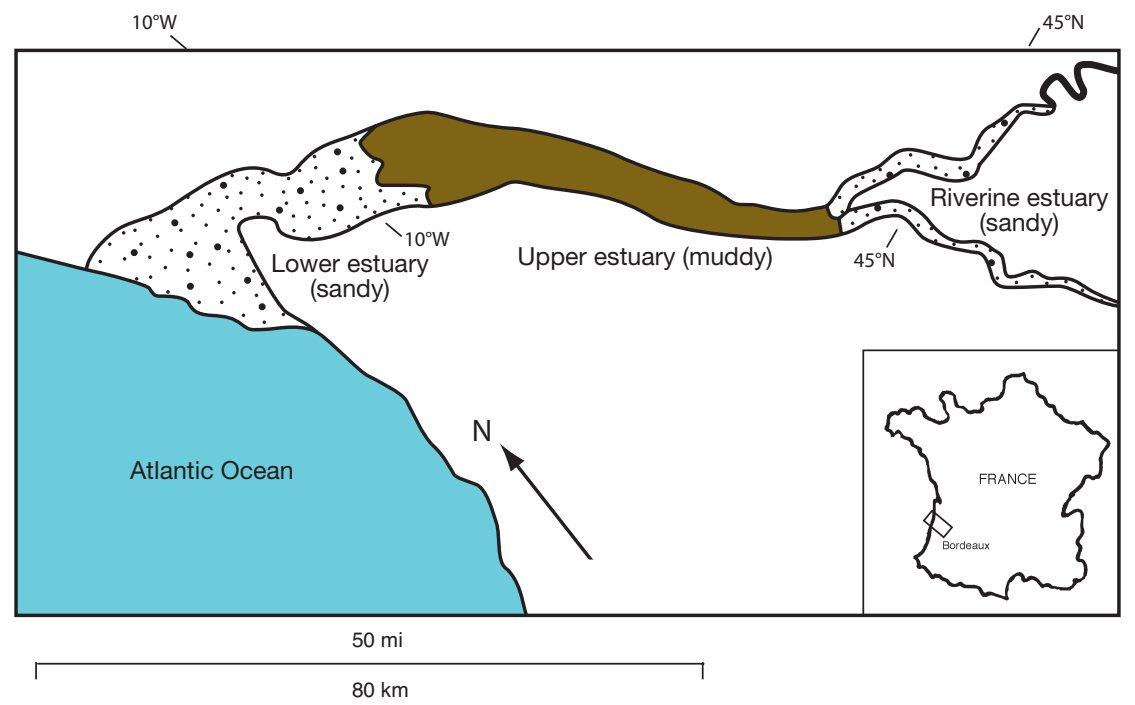

FIGURE 13-Diagrammatic map of the modern Gironde Estuary below Bordeaux, France (from Archer and Feldman, 1995, p. 130; after Allen, 1991). The lower estuary, upper estuary, and riverine estuary mapped here correspond to the outer, central, and inner estuary of Dalrymple et al. (1992).

calculate short-term accumulation rates. In general, accumulation rates on tidal flats are among the most rapid of any depositional setting (Kvale and Archer, 1990, p. 572; Enos, 1991, p. 78; Lanier et al. 1993, p. 869; Greb and Archer, 1998, p. 81), at least for very short intervals of days to decades, the time scale particularly relevant to load deformation.

The study interval at Lone Star was divided into an upper and lower interval by the accident of exposure, but also by sedimentary characteristics. Sandstone channels and extensive soft-sediment deformation characterize the upper interval (fig. 5 , sections 9-15). Laterally persistent thin siltstone beds within mudstone typify the lower interval (fig. 5, sections 1-7). Both intervals are interpreted as tidal deposits; why are they so different? Channels and increased soft-sediment deformation appear to be cause and effect, respectively, so the incision of channels is the key question. Did current energies increase, perhaps because of increased runoff or breaching of a channelmouth bar? No change in grain size is noticeable, although the percentage of sand is higher in the upper interval because sand is dominant in the channel fills. Incision might result from a drop in base level, in this case, sea level. Tidal sedimentation continued into the upper interval, however, so any shift would have been within the tidal range, inferred above to be microtidal or mesotidal. Alternatively, a rise in sea level, necessarily less than the tidal range, might have shifted the setting from the uppermost, non-channeled tidal flat, into a lower, channeled regimen. This would be more consistent with the overall transgressive trend. There is little evidence for a choice among these alternatives.

In summary, the Lawrence Formation exposed at Lone Star Lake is interpreted as a tide-influenced, upper (central) estuary, mud-flat sequence dissected by discrete sand- and mud-filled channels. This interpretation is consistent with the conclusions of low-energy, restricted, nearshore deposits suggested by Hakes $(1972,1976)$ from trace fossils. The lower Williamsburg coal at the top of the study interval was apparently deposited in a brackish-to-freshwater swamp as the estuary filled. Our results support and strengthen conclusions of Lanier (1993) concerning this sequence. Deformation structures throughout the sequence are interpreted as soft-sediment deformation resulting from rapid deposition with inverse density gradients in the original sediment.

\section{Discussion}

Stepping back to look at the overall sedimentation of the Ireland Sandstone Member provides the context for the Lone Star exposures and in turn may enhance understanding of the Ireland and the encompassing Amazonia cyclothem (Heckel, 2002; sequence 6 of Feldman et al. 2005, p. 357). Interpretations for the entire sequence using as a vantage point the postage-stampscale outcrop (now destroyed) at Lone Star spillway may appear presumptuous, but by standing on the shoulders of prior giant studies, we can see the big picture. The depositional setting of the upper Ireland Sandstone Member (table 1) can be summarized according to the attributes of incised valleys set out by Dalrymple (2006, p. 7).

A high rate of accommodation for this location on the stable craton (table 1) may be inferred on first principles from high-amplitude oscillations of sea level resulting from contemporaneous continental glaciation in the Southern Hemisphere, the presumed driver of midcontinent cyclicity. At the local scale, the accumulation of more than $15 \mathrm{~m}$ of uniform tidal deposits (base of exposure to base of Amazonia Limestone Member, interrupted briefly by coal deposition), a considerable thickness for the midcontinent, indicates that accommodation kept pace with sedimentation. Sedimentation was inferred to be rapid, so slightly circular logic indicates rapid accommodation. As the channel-filling Ireland Sandstone Member is fluvial and the overlying rocks show increasing marine influence (Feldman et al., 2005, p. 357), the entire interval is transgressive. This is true up to the Amazonia Limestone Member, with the exception of the fleeting tryst with the shoreline that resulted in the lower Williamsburg coal. Thus accommodation outstripped sedimentation throughout this interval. The upper part or top of the Amazonia marks maximum flooding and the beginning of a thin highstand systems tract (HST; Feldman et al., 2005, p. 364) 
that led to prolonged exposure with soil development beneath the upper Williamsburg coal (fig. 3; Joeckel, 1994; Feldman et al., 2005).

Evaluating the sources of sediment (table 1) is more problematic. Tidal processes generally transport marine sediment landward. A marine contribution in this setting, however, would be expected to contain appreciable carbonate, which is absent in the tidal deposits. Feldman et al. (2005, p. 364) note that the HST of their Amazonia sequence, which begins with the Ireland, includes "limestone on upper shelf," [part of the Amazonia] but also considerable shale. On the other hand, the Ireland Sandstone Member and lateral correlatives in the Lawrence Formation include volumes of silt and clay, so the fluvial end of the estuary may have supplied much of the mud to the higher tidal flats. Fluvial supply was apparently high. Marine supply may have been low or may have been moderate.

The size of the sediment varied fairly regularly from cobbles of limestone, shale, coal, and phosphate in the basal valley fill (fig. 3; Bowsher and Jewett, 1943; Feldman et al., 2005, p. 357), through crossbedded, fine- to medium-grained sandstone in the fluvial fill (O’Connor, 1960), up to $50 \mathrm{~m}$ thick (Sanders, 1959), grading upward to mudstone with subordinate siltstone in thin laminae and very fine grained sandstone, virtually confined to small channels, in the tidal estuarine deposits.

The Lone Star site was at least $150 \mathrm{~km}$ from the limit of incision by the Ireland valley, which probably extended into Woodson and Greenwood counties (fig. 3) and perhaps to the shelf-edge in southernmost Kansas. The Ireland Sandstone Member can be traced at least to Greenwood County (Sanders, 1959), but incision is difficult to establish in the absence of marker beds above the Haskell Limestone Member (fig. 3). The distance to the mouth of the postulated estuary was probably a moving target, as slight fluctuations in sea level or sediment supply could displace the shoreline dramatically in the very flat Pennsylvanian landscape.
This poses the question, were the interfluves of the Ireland drainage network eventually submerged and covered with sediment? This seems likely as the only good marker bed within this sequence, the Amazonia Limestone Member, although discontinuous (fig. 3), can be recognized from central Kansas into Missouri, Nebraska, and Iowa (Feldman et al., 2005, fig. 5). More to the point, though, how extensive are the tidal-estuarine deposits? In principle, it should be possible to distinguish the tidal deposits of the Ireland from the underlying Robbins Shale Member, generally considered "prodeltaic" (Ball, 1985). However, this requires good outcrops and a careful study that has not been undertaken. Moreover, a paleosol, which is to be expected at this sequence boundary and would certainly facilitate a study, has not yet been recognized (Feldman et al., 2005, p. 357).

Despite some uncertainty about drowning of the interfluves, the generally transgressive character of the Amazonia cyclothem, up to the Amazonia Limestone Member near the top, indicates that the Ireland paleovalley was filled and the interfluves were eventually flooded during transgression. This would qualify the Ireland incised valley as "overfilled" in the sense of Garrison and van den Bergh (2006).

Transgression in the Amazonia cyclothem was not quite continuous, however. The paralic coal of the lower Williamsburg represents an interruption when the depositional surface caught up with sea level briefly, perhaps for as little as 1,000 years (Archer et al., 1993, p. 1-20). The distribution of the coal in cross section (fig. 3) strongly suggests that it was confined to the Ireland channel. If this is true, then the channel was not quite filled yet, and the interfluves must have been exposed while the channel axis was a coal swamp, probably at the head of a narrow estuary.

Elsewhere, rhythmically laminated sequences very similar to the sequence at Lone Star Lake spillway have commonly been interpreted as tide-dominated deposits. Kvale et al. (1989) studied

TABLE 1-Depositional setting of Ireland Sandstone Member at Lone Star spillway, based on attributes of Dalrymple (2006, p. 7).

\begin{tabular}{lll}
\hline \hline Attribute & Ireland Sandstone Member & Remarks \\
\hline Age & Upper Pennsylvanian (Stephanian) & \\
Tectonic setting & Stable cratonic interior & \\
Accommodation & High & Glacio-eustatic control \\
Sediment supply & Fluvial high, marine low? & $\begin{array}{c}\text { Deformation attributed to rapid sedimentation. Channel-fill sandstone is } \\
\text { fluvial }^{1}\end{array}$ \\
& & $\begin{array}{c}\text { Tidal deposits equivocal } \\
\end{array}$
\end{tabular}

Sediment caliber

Climate

Location along valley

Mud $>$ silt $>$ sand

Humid seasonal, sub-tropical

Inland, near parasequence shoreline
Low-latitude setting; climate evidence from Feldman et al. (2005)

Incision extended to southern $\operatorname{Kansas}^{3}(\sim 150 \mathrm{~km})$

Paralic coal represents short-lived shoreline ${ }^{4}$

Depositional environment Tidal estuary

\footnotetext{
${ }^{1}$ Bowsher and Jewett, 1943; O'Connor, 1960; Feldman et al., 2005

${ }^{2}$ See discussion in text

${ }^{3}$ Feldman et al., 2005, p. 357: Sanders, 1959

${ }^{4}$ Perhaps 1,000 or 2,000 years (Archer et al., 1993, p. 1-20)
} 
laminated siltstones within the Mansfield Formation of Orange County, Indiana. The stacked, coarsening-upward siltstone laminations in that study were interpreted as deposits from a tideinfluenced environment in which neap- and spring-tide variations were recorded as variations in thickness of lamination. Other examples from many similar deposits (cf. Klein, 1970; Weimer et al., 1982) are the Elatine Formation (late Precambrian) in Australia (Williams, 1988; Sonett et al., 1988) and the Francis Creek Shale Member of the Carbondale Formation (Middle Pennsylvanian) of northern Illinois (Kuecher et al., 1990). The Brazil Formation (Lower Pennsylvanian) in Indiana (Kvale and Archer, 1990) has channel-fill sequences similar to those observed in the Lawrence Formation at the Lone Star spillway.

The recognition of sedimentary structures and architecture within the Tonganoxie Sandstone Member of the Douglas Group (fig. 2) indicative of transitions from fluvial to tidal estuarine to marine deposition from northeast to southwest across Kansas (Archer et al., 1993, 1994; Feldman et al., 1995) has popularized the estuarine model for deposition of sand and shale intervals in the midcontinent. It is unlikely that most midcontinent units would fit into the dimensions of any estuary, but the occurrence of the study interval near the top of the Ireland Sandstone Member incised-valley fill greatly strengthens the case for an estuarine setting. The Ireland Sandstone Member is strikingly similar to the underlying Tonganoxie Sandstone Member in many respects (Sanders, 1959; O'Connor, 1960; Ball, 1964; Archer et al., 1994), but it has not received the extensive regional study necessary to delineate similar facies trends. This is in part because the trend of the Ireland paleovalley in outcrop is roughly westward (Sanders, 1959; O’Connor, 1960), severely limiting lateral exposure in the NNE-SSW-trending outcrop belt.

Despite the indications of tidal activity and the superposition of a coal bed and eventually a regional soil marking a sequence boundary near the top of the Lawrence Formation (Joeckel, 1994; Feldman et al., 2005), no indications of exposure such as desiccation cracks, raindrop impressions, or root casts were observed within the study interval of the Lawrence Formation. The only exception is the interval of blocky, gleyed mudstone with "extensive rooting" (Archer et al., 1993, p. 1-22) beneath the lower Williamsburg coal.

\section{Conclusions}

Exposures of the upper part of the Ireland Sandstone Member of the Lawrence Formation at the Lone Star spillway consist of interlaminated shale, siltstone, and sandstone with pinstripe, lenticular, and minor flaser lamination. Channel-form sandstone and mudstone lenses are prominent in the upper part of the study interval. Bedding patterns, sedimentary structures, bipolar paleocurrents, and dominance of mud indicate deposition in a tide-dominated upper estuary. Modern depositional systems comparable to the Lone Star Lake site in lithology and sedimentary structures are found in large estuaries. The numerous deformational features were imposed on soft sediment rapidly deposited with inverse density gradients. These interpretations support and somewhat amplify those of Archer and West (1991), Archer (1993), Lanier (1993), and Feldman et al. (2005) for this part of the Lawrence Formation.

Acknowledgments - We thank classmates in sedimentology who measured detailed sections at the Lone Star spillway: Jeremy Littlejohn, Jon Holmgren, Ryan Pearson, Matt Brookshier, Glenn Newell, Jeff Zuehlke, John Keller, Lisa Armatas, Victoria G. Christensen, and Doug Linger. Sections measured by the 1992 class: Matthew Briney, Peter Cattaneo, Yenli Choong, Merritt Forman, Richard Godsil, Monica Hochanadel, Terrence Huettl, Sheila Kortlucke, Daria Sander, Gregory Siek, and Robert Younger were integrated, or in some cases served as the primary source, in fig. 5. Thanks to Steve Franklin, laboratory instructor, photogenic scale, and enthusiast, and Brian Macy, who helped scan initial photographs, for their involvement in this project. Greg Seik helped generate interest in the project but had to move on before it was completed. Alex Martinez and Scott Beaty labored heroically to meld the outcrop photographs into a single panorama, but were frustrated by 1995 technology. It remained for John Charlton (KGS) to merge the photographic overlaps and produce the panorama using Adobe Photoshop ${ }^{\circledR} \mathrm{CS} 3$, extended version. Jennifer Sims (KGS) produced the final figures. All this support is gratefully acknowledged.

Helpful reviews of an early version of the manuscript were generously provided by Allen W. Archer, Kansas State University, and Howard Feldman, then of the Kansas Geological Survey. The final manuscript benefited from reviews by George deVries Klein, Sed-Strat Geoscience Consultants, Inc., Sugar Land, Texas, and Howard Feldman, now with ExxonMobil Exploration Co. 


\section{References}

Allen, G. P., 1991, Sedimentary processes and facies in the Gironde Estuary - a Recent model for macrotidal estuarine systems; in, Clastic Tidal Sedimentology, D. G. Smith, G. E. Reinson, B. A. Zaitlin, and R. A. Rahmani, eds.: Canadian Society of Petroleum Geologists, Memoir 16, p. 29-40.

Allen, J. R. L., 2003, Load structures; in, Encyclopedia of Sediments and Sedimentary Rocks, G. V. Middleton, ed.: Kluwer Academic, Dordrecht, p. 413-414.

Archer, A. W., 1991, Modeling of tidal rhythmites using modern tidal periodicities and implications for short-term sedimentation rates; in, Sedimentary Modeling - Computer Simulations for Improved Parameter Definition, E. K. Franseen, W. L. Watney, C. G. St. C. Kendall, and W. C. Ross, eds.: Kansas Geological Survey, Bulletin 233, p. 185-194.

Archer, A. W., 1993, Tidal processes in the fluvio-tidal transition within estuaries; in, Incised Paleovalleys of the Douglas Group in Northeastern Kansas; Field Guide and Related Contributions, A. W. Archer, H. R. Feldman, and W. P. Lanier, eds.: Kansas Geological Survey, Open-file Report 93-24, section 2, 35 p.

Archer, A. W., 1998, Hierarchy of controls on cyclic rhythmite deposition-Carboniferous basins of eastern and midcontinental U.S.A.; in, Tidalites-Processes and Products, C. R. Alexander, R. A. Davis, and V. J. Henry, eds.: Society of Economic Paleontologists and Mineralogists, Special Publication 61, p. 59-68.

Archer, A. W., and Feldman, H. R., 1995, Incised valleys and estuarine facies of the Douglas Group (Virgilian) - Implications for similar Pennsylvanian sequences in the U.S. midcontinent; in, Sequence Stratigraphy of the Midcontinent, N. J. Hyne, ed.: Tulsa Geological Society, p. 119-140.

Archer, A. W., Feldman, H. R., and Lanier, W. P., eds., 1993, Incised paleovalleys of the Douglas Group in northeastern Kansas-Field guide and related contributions: Kansas Geological Survey, Openfile Report 93-24, 243 p.

Archer, A. W., Lanier, W. P., and Feldman, H. R., 1994, Stratigraphy and depositional history within incised-paleovalley fills and related facies, Douglas Group (Missourian/Virgilian; Upper Carboniferous) of Kansas, U.S.A.; in, Incised-valley SystemsOrigin and Sedimentary Sequences, R. W. Dalrymple, R. Boyd, and B. A. Zaitland, eds.: Society of Economic Paleontologists and Mineralogists, Special Publication 51, p. 175-190.

Archer, A. W., and West, R., 1991, Lone Star Lake spillway, upper Lawrence shale; in, Upper Pennsylvanian (Virgilian and Missourian) Cyclothems in the Lawrence, Kansas, Area, W. L. Watney, R. West, C. Maples, and P. Denham, eds.: Kansas Geological Survey, Open-file Report 91-22, p. 89-94.

Ball, D. S., 1985, The Pennsylvanian Haskell-Cass section, a perspective on controls of midcontinent cyclothem deposition: M.S. thesis, University of Kansas, Lawrence, 147 p.

Ball, S. M., 1964, Stratigraphy of the Douglas Group (Pennsylvanian, Virgilian) in the northern midcontinent region: Ph.D. dissertation, University of Kansas, Lawrence, 490 p.

Beard, D. C., and Weyl, P. K., 1973, Influences of texture on porosity and permeability of unconsolidated sand: American Association of Petroleum Geologists, v. 57, p. 349-369.

Bowsher, A. L., and Jewett, J. M., 1943, Coal resources of the Douglas Group in east-central Kansas: Kansas Geological Survey, Bulletin 46, p. 94.

Dalrymple, R. W., 2006, Incised valleys in time and space-An introduction to the volume and an examination of the controls on valley formation and filling; in, Incised Valleys in Time and Space, R. W. Dalrymple, D. A. Leckie, and R. W. Tillman, eds.: Society of Economic Paleontologists and Mineralogists, Special Publication 85, p. 5-12.
Dalrymple, R. W., Knight, R. J., Zaitland, B. A., and Middleton, G. V., 1990, Dynamics and facies model of a macrotidal sand-bar complex, Cobiquid Bay-Salmon River Estuary (Bay of Fundy): Sedimentology, v. 37, p. 577-612.

Dalrymple, R. W., Zaitland, B. A., and Boyd, R., 1992, Estuarine facies models - Conceptual basis and stratigraphic implications: Journal of Sedimentary Petrology, v. 62, p. 1,130-1,146.

Enos, Paul, and Sawatsky, L. H., 1981, Pore networks in Holocene carbonate sediments: Journal of Sedimentary Petrology, v. 51, p. 961-985.

Enos, Paul, 1991, Sedimentary parameters for computer modeling; in, Sedimentary Modeling - Computer Simulations and Methods for Improved Parameter Definition, E. K. Franseen, W. L. Watney, C. G. St. C. Kendall, and W. Ross, eds.: Kansas Geological Survey, Bulletin 223, p. 63-95.

Feldman, H. R., Franseen, E. K., Joeckel, R. M., and Heckel, P. H., 2005, Impact of longer-term climate shifts on architecture of highfrequency sequences (cyclothems), Pennsylvanian of midcontinent U.S.A.: Journal of Sedimentary Research, v. 75, p. 350-368.

Feldman, H. R., Gibling, M. R., Archer, A. W., Wightman, W. G., and Lanier, W. P., 1995, Stratigraphic architecture of the Tonganoxie paleovalley fill (lower Virgilian) in northeastern Kansas: American Association of Petroleum Geologists, Bulletin, v. 79, p. 1,0191,043 .

Folk, R. L., 1973, Evidence for peritidal deposition of Devonian Caballos Novaculite, Marathon basin, Texas: American Association of Petroleum Geologists, Bulletin, v. 57, p. 702-725.

Garbish, J. O., Hageman, S. A., Hecht, G. D., Krogstad, K., Robb, A. J., Ross, K., Smith, B., and Tilley, B., 1991, The Wathena Shale Member of the Lawrence Formation (Virgilian, U. Pennsylvanian) of eastern Kansas; a tidal estuary (abs.): Geological Society of America., Rocky Mountain and South-Central Sections, 1991 Annual Meeting, Abstracts with Program, p. 23.

Garrison, J. R., and van den Bergh, T. C. V., 2006, Effects of sedimentation rate, rate of relative rise of sea level, and duration of sea-level cycle on the filling of incised valleys-Examples of filled and "overfilled" incised valleys from the upper Ferron Sandstone, Last Chance Delta, east-central Utah; in, Incised Valleys in Time and Space, R. W. Dalrymple, D. A. Leckie, and R. W. Tillman, eds.: Society of Economic Paleontologists and Mineralogists, Special Publication 85, p. 239-279.

Gradzinski, R., and Doktor, M., 1995, Peat compaction as a factor in burial of high upright stems - An example from the Upper Carboniferous Mudstone Series, upper Silesian basin, Poland: Abstracts of the XIII International Congress on CarboniferousPermian, Polish Geological Institute, p. 47.

Greb, S. F., and Archer, A. W., 1998, Annual sedimentation cycles in rhythmites of Carboniferous tidal channels; in, Tidalites - Processes and Products, C. R. Alexander, R. A. Davis, and V. J. Henry, eds.: Society of Economic Paleontologists and Mineralogists, Special Publication 61, p. 75-83.

Hakes, W. G., 1972, Trace fossils and the depositional environment of the Lawrence Shale (Upper Pennsylvanian) of eastern Kansas: M.S. thesis, University of Kansas, Lawrence, 55 p.

Hakes, W. G., 1976, Trace fossils and depositional environment of four clastic units, Upper Pennsylvanian megacyclothems, northeastern Kansas: University of Kansas, Paleontological Contribution, Article $63,46 \mathrm{p}$.

Heckel, P. H., 2002, Genetic stratigraphy and conodont biostratigraphy of upper Desmoinesian-Missourian (Pennsylvanian) cyclothem succession in midcontinent North America; in, Carboniferous and Permian of the World; XIV ICCP Proceedings, L. V. Hills, C. M. Henderson, and E. W. Bamber, eds.: Canadian Society of Petroleum Geologists, Memoir 19, p. 99-119. 
Joeckel, R. M., 1994, Virgilian (Upper Pennsylvanian) paleosols in the upper Lawrence Formation (Douglas Group) and in the Snyderville Shale Member (Shawnee Group, Oread Formation) of the northern midcontinent, U.S.A.-Pedogenic contrasts in a cyclothem sequence: Journal of Sedimentary Research, v. A64, p. 853-866.

Joeckel, R. M., 1995, Virgilian (Upper Pennsylvanian) paleosols in the upper Lawrence Formation (Douglas Group) and in the Snyderville Shale Member (Shawnee Group, Oread Formation) of the northern midcontinent, U.S.A.-Pedogenic contrasts in a cyclothem sequence: Journal of Sedimentary Research-Reply, v. A65, p.714718.

Klein, G. deV., 1970, Tidal origin of a Precambrian quartzite - the lower fine-grained quartzite (Middle Dalradian) of Islay, Scotland: Journal of Sedimentary Petrology, v. 40, p. 973-985.

Klein, G. deV., 1977, Clastic tidal facies: Continuing Education Publishing Company, Champaign, Illinois, 149 p.

Kuecher, G. J., Woodland, B. G., and Broadhurst, F. M., 1990, Evidence for deposition from individual tides and of tidal cycles from the Francis Creek Shale (host rock to the Mazon Creek biota), Westphalian D (Pennsylvanian), northeastern Illinois: Sedimentary Geology, v. 68, p. 211-221.

Kvale, E. P., and Archer, A. W., 1990, Tidal deposits associated with low-sulfur coals, Brazil Fm. (Lower Pennsylvanian), Indiana: Journal of Sedimentary Petrology, v. 60, p. 563-574.

Kvale, E. P., Archer, A. W., and Johnson, H. R., 1989, Daily, monthly, and yearly tidal cycles within laminated siltstones of the Mansfield Formation (Pennsylvanian) of Indiana: Geology, v. 17, p. 365-368

Lanier, W. P., 1993, Bedform sedimentology of the Lone Star spillway and Buildex quarry stops; in, Incised Paleovalleys of the Douglas Group in Northeastern Kansas; Field Guide and Related Contributions, A. W. Archer, H. R. Feldman, and W. P. Lanier, eds.: Kansas Geological Survey, Open-file Report 93-24, section 4, 10 p.

Lanier, W. P., Feldman, H. R., and Archer, A. W., 1993, Tidally influenced overbank sedimentation in a fluvial to estuarine transition, Douglas Group, Missourian-Virgilian, Kansas: Journal of Sedimentary Petrology, v. 63, p. 860-873.

Lanier, W. P., and Tessier, Bernadette, 1998, Climbing-ripple bedding in the fluvio-estuarine transition-A common feature associated with tidal dynamics (modern and ancient analogues); in, Tidalites-Processes \& Products, C. R. Alexander, R. A. Davis, and V. J. Henry, eds.: Society of Economic Paleontologists and Mineralogists, Special Publication 61, p. 109-117.

Lawrence Journal-World, 30 June 1988, p. 1A, 9A.

McBride, E. F., and Folk, R. L., 1979, Features and origin of Italian radiolarites deposited on continental crust: Journal of Sedimentary Petrology, v. 49, p. 837-868.

McKee, E. D., 1957, Flume experiments on the production of stratification and cross stratifications: Journal of Sedimentary Petrology, v. 27, p. 129-134.

Middleton, G. V., 2003, Convolute lamination; in, Encyclopedia of Sediments and Sedimentary Rocks, G. V. Middleton, ed.: Kluwer Academic, Dordrecht, p. 168.

Moore, R. C., 1949, Divisions of the Pennsylvanian System in Kansas: Kansas Geological Survey, Bulletin 83, 283 p.

Neuendorf, K. E., Mehl, J. P., Jr., and Jackson, Julia A., eds., 2005, Glossary of geology, 5th edition: American Geological Institute, Alexandria, VA, $779 \mathrm{p}$.
O’Connor, H. G., 1960, Geology and ground-water resources of Douglas County, Kansas: Kansas Geological Survey, Bulletin 148, 200 p.

Owen, G., 1987, Deformation processes in unconsolidated sands; in, Deformation of Sediments and Sedimentary Rocks, M. E. Jones and R. M. F. Preston, eds.: Geological Society, Special Publication 29, p. 11-24.

Owen, G., 2003a, Ball-and-pillow (pillow) structure; in, Encyclopedia of Sediments and Sedimentary Rocks, G. V. Middleton, ed.: Kluwer Academic, Dordrecht, p. 39-40.

Owen, G., 2003b, Pseudonodules; in, Encyclopedia of Sediments and Sedimentary Rocks, G. V. Middleton, ed.: Kluwer Academic, Dordrecht, p. 549-551.

Pettijohn, F. J., Potter, P. E., and Siever, R., 1987, Sand and sandstone: Springer-Verlag, Berlin, 2nd edition, $553 \mathrm{p}$.

Reineck, H. E., and Singh, I. B., 1975, Depositional sedimentary environments: Springer-Verlag, Berlin, 439 p.

Reineck, H. E., and Wunderlich, Friedrich, 1968, Classification and origin of flaser and lenticular bedding: Sedimentology, v. 11, p. 99-104.

Robb, A. J., III, comp., 1991, Studies in paleoecology of the Wathena Shale Member of the Lawrence Formation (Virgilian: U.

Pennsylvanian) of eastern Kansas: Kansas Geological Survey, Open-file Report 91-3, 53 p.

Rutan, Debra, 1980, The petrology and depositional environments of the Pennsylvanian Lawrence Formation in eastern Kansas: M.S. thesis, University of Kansas, Lawrence, 120 p.

Sanders, D. T., 1959, Sandstones of the Douglas and Pedee Groups in northeastern Kansas: Kansas Geological Survey, Bulletin 134, pt. 3, p. 125-159.

Seilacher, A., 1967, Bathymetry of trace fossils: Marine Geology, v. 5, p. 413-428.

Sonnett, C. P., Finney, S. A., and Williams, C. R., 1988, The moon's orbit in the late Precambrian and the Elatina sandstone: Nature, v. 335, p. 806-808.

Weimer, R. J., Howard, J. D., and Lindsay, D. R., 1982, Tidal flats and associated tidal channels; in, Sandstone Depositional Environments, P. A. Scholle and D. Spearing, eds.: American Association of Petroleum Geologists, Memoir 31, p. 191-245.

West, R. R., and Maples, C. G., 1993, Paleoecology of the Douglas Group (Pennsylvanian, Kansas) - Status; in, Incised Paleovalleys of the Douglas Group in Northeastern Kansas; Field Guide and Related Contributions, A. W. Archer, H. R. Feldman, and W. P. Lanier, eds.: Kansas Geological Survey, Open-file Report 93-24, section 7, 8 p.

Williams, G. E., 1988, Cyclicity in the late Precambrian Elatina Formation, South Australia-Solar or tidal signatures?: Climatic Change, v. 13, p. 117-128.

Wunderlich, Friedrich, 1970, Genesis and environment of the "Nellenköpfchenschichten" (Lower Emsian; Rhenian Devonian) at locus typicus in comparison with modern coastal environments of the German Bay: Journal of Sedimentary Petrology, v. 40, p.102130.

Zeller, D. E., ed., 1968, The stratigraphic succession in Kansas: Kansas Geological Survey, Bulletin 189, p. 27-39. 